\title{
Rancang Bangun Aplikasi SPPD KPPN Medan II Berbasis Web Menggunakan Metode Prototyping
}

\author{
Crystal Jelita Lumban Tobing \\ Universitas Samudra \\ e-mail: crystaljelitalumbantobing@gmail.com
}

\begin{abstract}
Abstrak
KPPN Medan II merupakan salah satu unit organisasi pemerintah pada Kementerian Keuangan. Dimana pimpinan serta para pegawai yang bekerja di KPPN Medan II tersebut selalu melakukan perjalanan dinas antar kota maupun diluar kota. Dengan keadaan tersebut maka pembuatan dokumen SPPD mengalami tingkat intensitas aktivitas perjalanan dinas yang dilakukan oleh para pegawai KPPN Medan II dapat dikatakan sering. Sehingga didalam pembuatan SPPD di KPPN Medan II tersebut masih menggunakan cara manual yaitu pencatatan melalui microsoft word yang dalam artian kurang efektif dan efisien. Dalam penamaan pegawai yang mendapat tugas resmi, petugas memasukkan data karyawan secara manual yang menerima surat perjalanan resmi secara otomatis rawan hilang karena data ditulis secara manual. Aplikasi SPPD berbasis web dibangun dengan menerapkan metode prototyping ini nantinya diharapkan dapat mempermudah petugas pengelola SPPD KPPN Medan II dalam pembuatan SPPD yang efektif, efisien, akurat, hemat waktu, dan tidak rawan kehilangan data SPPD para pegawai KPPN Medan II yang akan,sedang, serta telah melakukan perjalanan dinas dikarenakan adanya database khusus untuk menampung segala file-file SPPD.
\end{abstract}

Kata Kunci: Aplikasi, SPPD, KPPN Medan II, Website

\begin{abstract}
KPPN Medan II is one of the government organization units at the Ministry of Finance. Where leaders and employees who work at KPPN Medan II always carry out official trips between cities and outside the city. With these conditions, making SPPD documents experiencing the intensity of official travel activities carried out by employees of KPPN Medan II can be said frequently. So that in making SPPD in KPPN Medan II is still using the manual method that is recording through Microsoft Word which in the sense is less effective and efficient. In naming employees who get official assignments, officers manually entering employee data that receives official travel letters are prone to being lost because data is manually written. Web-based SPPD application is built by applying this prototyping method which is expected to facilitate SPPD KPPN Medan II management officers in making SPPD that is effective, efficient, accurate, time-saving, and not prone to loss of SPPD data of KPPN Medan II employees who will, are, and has made official trips due to the existence of a special database to accommodate all SPPD files.
\end{abstract}

Keywords: Application, SPPD, KPPN Medan II, Website

\section{Pendahuluan.}

Sebuah perusahaan atau organisasi pasti ada pada aktivitas yang dimana karyawan atau anggota tertentu memiliki keperluan yang harus dilakukan diluar tempat kedudukannya, aktivitas ini juga disebut perjalanan dinas. Menteri Keuangan Republik Indonesia mengatur prosedur dalam melaksanakan perjalanan dinas, diantaranya PMK Nomor 113/PMK.5/2012 tentang perjalanan dinas dalam negeri bagi pejabat negara, pegawai negeri, dan pegawai tidak tetap. Sesuai dengan Pasal 1
Ayat (1) PMK Nomor 113/PMK.05/2012, yang berbunyi: "perjalanan dinas dalam negeri yang selanjutnya disebut perjalanan dinas adalah perjalanan ke luar tempat kedudukan yang dilakukan dalam wilayah Republik Indonesia untuk kepentingan negara". Sehingga aktivitas perjalanan dinas memang dilakukan hanya karena kepentingan negara, perusahaan, organisasi, atau yang berhubungan dengan jabatan sesorang, bukan karena kepentingan pribadi.(Umam, n.d.) 
Surat Perintah Perjalanan Dinas (SPPD) merupakan dokumen yang dibuat ketika seorang pimpinan dan anggota yang bekerja pada sebuah instansi atau perusahaan tersebut akan melakukan pekerjaan diluar kantor dengan jarak yang telah ditentukan. Kantor Pelayanan Perbendaharaan Negara (KPPN) Medan II merupakan salah satu unit organisasi pemerintah pada Kementerian Keuangan mempunyai tanggung jawab yang sama dengan unit organisasi pemerintah yang lain dalam mewujudkan tata kelola pemerintah yang baik (good goverment). Oleh karena itu, pimpinan serta para pegawai yang bekerja di KPPN Medan II tersebut mayoritas Pegawai Negeri Sipil (PNS) selalu melakukan perjalanan dinas.

Dengan keadaan tersebut maka pembuatan dokumen SPPD mengalami tingkat intensitas aktivitas perjalanan dinas yang dilakukan oleh para pegawai Kantor Pelayanan Perbendaharaan Negara (KPPN) Medan II dapat dikatakan sering, namun walaupun keadaannya demikian di KPPN Medan II tidak ada database yang menyimpan data SPPD, sehingga penanganan SPPD masih sekedar saja atau disebut manual selain memerlukan banyak tenaga juga tidak tersistem secara baik. Perhitungan yang manual sering dijumpai banyak kesalahan, disamping boros waktu, boros materi dan boros tenaga. Untuk mengatasi keadaan tersebut maka dirancang dan dibangun aplikasi mengenai SPPD, database dibuat dalam format SQL. SQL merupakan sebuah bahasa (language) yang digunakan untuk mengakses data di dalam sebuah database relasional. Hingga saat ini hampir seluruh server database atau software database mengenal dan mengerti bahasa SQL karena mudah dipahami dan cepat dalam penggunaan. Sehingga setiap saat dapat dipanggil data-datanya dengan cepat, dan merupakan suatu aktifitas dari personal (pekerja) untuk menjalankan roda instansi tersebut (Bangun, Surat, Perjalanan, Negara, \& li, 2018)

\section{Metode Penelitian}

Dalam membangun atau mengembangkan sebuah perangkat lunak maupun sistem informasi diperlukan sebuah metode model khusus untuk pengembangan sebuah sistem, salah satunya yang paling sering digunakan atau dikatakan model yang lebih cocok digunakan dalam pengembangan sebuah sistem adalah menggunakan model System Development Life Cycle (SDLC). Model SDLC memiliki banyak varian metode dalam mengembangkan sebuah sistem. Pengimplementasian model SDLC dalam mengembangkan sebuah sistem aplikasi SPPD KPPN Medan II berbasis website ini menggunakan metode Prototyping. Sebuah model prototyping ini sebenarnya adalah sebuah pengembangan dari sebuah model waterfall, tetapi ada inovasi dalam penerapannya sehingga sedikit berbeda dari metode dasarnya.(Susanto, Andriana, Susanto, \& Andriana, n.d.)

Pengembangan sistem aplikasi SPPD KPPN Medan II berbasis website ini menggunakan metode prototyping. Menggunakan metode tersebut dikarenakan pembuatan sebuah sistem harus menyesuaikan dengan keinginan user (pengguna), yaitu dengan memberikan contoh dari setiap modul yang dibuat untuk ditunjukkan kepada user yang dalam hal ini adalah petugas pengelola SPPD, operator, dan para pegawai KPPN Medan II. Jika sudah cocok dan sesuai dengan keinginan user maka, kemudian dilanjutkan ke tahapan selanjutnya namun jika tidak dilakukan perbaikan sesuai dengan permintaan pengguna (user).

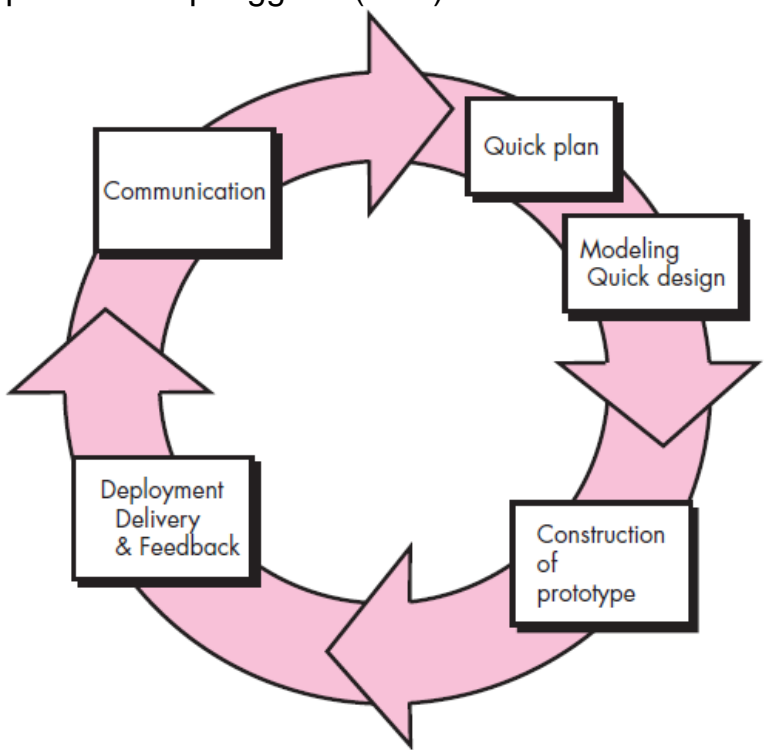

Gambar 1. Prototyping Method Sumber: (Informatika, Prototype, \& Evaluation, 2016)

Metode ini memiliki beberapa tahapan yang dilakukan, yaitu sebagai berikut: 


\section{1) Requirment Analysis}

Pada tahap ini, seorang pengembang dan operator serta pihak petugas pengelola SPPD KPPN Medan II bersama-sama melakukan identifikasi kebutuhan, mendefinisikan sebuah format sistem yang akan dibangun, serta batasan-batasan sistem yang akan dibangun.

\section{2) Build Prototype}

Pada tahapan yang kedua ini dibuat sebuah prototype dari sebuah sistem yang akan dibangun, tetapi prototype ini hanya difokuskan pada penyajian kepada pihak operator serta petugas pengelola SPPD KPPN Medan II meliputi inputan dan bentuk laporan yang sesuai dengan keinginan pihak operator (Kasubbag umum) dan kepala kantor PPN Medan II.

\section{3) Prototype Evaluation}

Pada tahapan ini dilakukan oleh pihak operator dan petugas pengelola SPPD KPPN Medan II apakah prototype yang dibuat sudah sesuai dengan kebutuhannya atau tidak, jika sesuai maka akan diimplementasikan, tetapi jika tidak prototype direvisi dan dibuat kembali untuk ditunjukkan kembali pada pihak operator dan petugas pengelola SPPD KPPN Medan II.

\section{4) Implementation}

Setelah prototype sesuai dengan kebutuhan dalam mengelola SPPD KPPN Medan II dan sudah disepakati bersama, maka tahapan implementasi dilakukan yakni dengan membuat sistem aplikasi yang sesungguhnya dengan menggunakan bahasa pemrograman yang sesuai.

\section{5) Testing}

Setelah sebuah sistem yang dibangun menjadi satu kesatuan sebuah aplikasi yang utuh dan siap pakai, sebelum digunakan diperlukan pengujian. Sistem pengujian dilakukan pertama kali dengan pengujian white box, pengujian dilakukan oleh seorang programmer atau seorang sistem analis. Kemudian dilakukan pengujian dengan white box, pengujian dilakukan oleh pengguna selain programmer. Pengujian ini dilakukan untuk mengetahui tingkat margin error dari sebuah sistem aplikasi sebelum digunakan oleh operator, petugas pengelola
SPPD KPPN Medan II, dan para pegawai serta pejabat KPPN Medan II.

\section{6) System Evaluation}

Tahapan ini dilakukan oleh pihak operator serta pengelola SPPD KPPN Medan II dengan melakukan evaluasi apakah sistem yang didapatkan sudah sesuai dengan yang diharapkan. Jika sebuah sistem sudah sesuai, maka akan diimplementasikan.

\section{7) Use the System}

Pada tahap ini adalah tahap penggunaan sebuah sistem yang sudah diuji dan sudah dievaluasi terlebih dahulu.

\section{Hasil dan Pembahasan}

\subsection{Pemodelan sistem}

Aplikasi SPPD KPPN Medan II berbasis website yang akan diterapkan meliputi banyak data yang dikelola pihak petugas pengelola SPPD KPPN Medan II, diantaranya data golongan para pegawai atau para pejabat KPPN Medan II, data para pegawai, data pejabat, data kegiatan dalam melakukan perjalanan dinas, data dasar, data pelaksana, data pengikut pelaksana, dan data biaya. Pada sistem ini operator yaitu Kasubbag umum KPPN Medan II punya hak akses sama dengan petugas pengelola sistem aplikasi SPPD berbasis web yaitu sama-sama dapat mengelola data pegawai, data pejabat tetapi operator tidak memiliki hak akses terhadap pengelolaan data kegiatan SPPD. Dan yang memiliki hak akses penuh terhadap sistem aplikasi tersebut adalah petugas pengelola SPPD KPPN Medan II. Sementara hak akses terakhir yaitu hak akses biasa untuk para pegawai yang memiliki hak akses hanya dapat melihat para pegawai dan laporan pegawai yang sedang dan telah melakukan perjalanan dinas kedalam atau keluar kota. (Informatika, Prototype, \& Evaluation, 2016).

Secara garis besar sebuah proses dalam sistem aplikasi SPPD KPPN Medan II berbasis web ini dimodelkan menggunakan data flow diagram sebagaimana gambar 2 . 


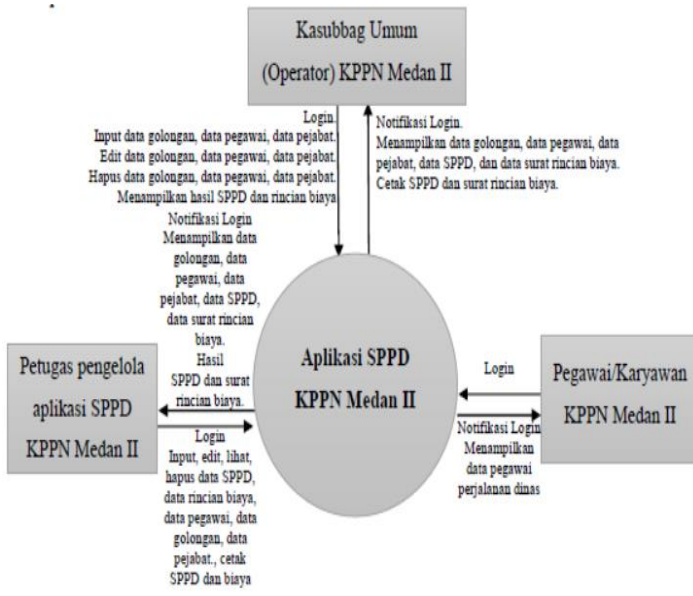

Gambar 2. Context diagram sistem aplikasi SPPD KPPN Medan II berbasis web.

Dari model context diagram diatas dapat decompose lagi menjadi data flow diagram level 1 sebagaimana gambar 2. Dalam data flow diagram level 1 ini lebih merinci lebih jelas aktifitas setiap entitas dan alur data.

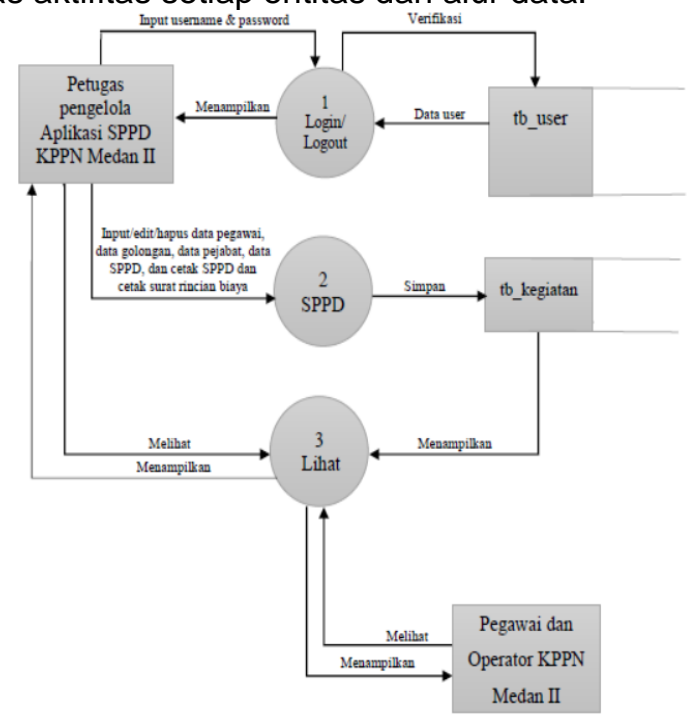

Gambar 3. DFD Level 1 sistem aplikasi SPPD KPPN Medan II berbasis web.

Pada alur data kali ini dijelaskan proses login/logout pada SPPD, petugas pengelola aplikasi SPPD KPPN Medan II masuk kedalam sistem dengan memasukkan username dan password kemudian di verifikasi oleh sistem dan ditampilkan kepada petugas pengelola Aplikasi SPPD KPPN Medan II, lalu petugas pengelola aplikasi SPPD KPPN Medan II menginput data SPPD dan disimpan pada tb_kegiatan kemudian ditampilkan agar operator dan pegawai bisa melihat data SPPD didalam sistem. Dari model DFD Level 1 diatas dapat decompose lagi menjadi DFD Level 2 sebagaimana gambar 3 .

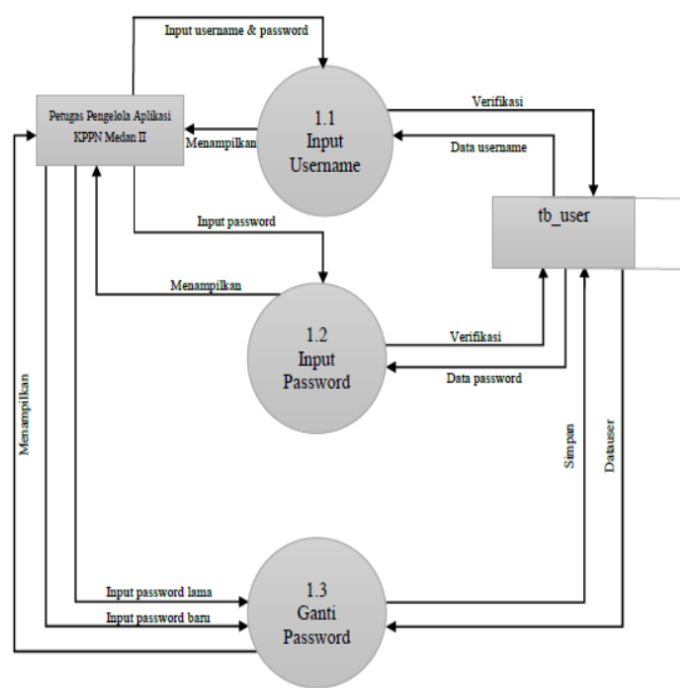

Gambar 4. DFD Level 2 proses login pada sistem.

Pada data flow diagram level 2 ini menjelaskan detail dari proses-proses yang ada pada DFD level 1. Dimana terdapat 2 gambar yaitu gambar pertama merupakan proses login dan gambar ke 2 merupakan gambar proses aplikasi SPPD KPPN Medan II. Pada gambar pertama dijelaskan bahwa proses login pertama-tama melalui petugas pengelola aplikasi SPPD KPPN Medan II yang menginput username dan password kemudian sistem akan verifikasi apakah itu merupakan petugas pengelola Aplikasi SPPD KPPN Medan II atau bukan. Apabila petugas pengelola Aplikasi SPPD Medan II, maka petugas pengelola Aplikasi SPPD KPPN Medan II dapat hak akses untuk mengganti password dan data akan ditampilkan kepada petugas pengelola Aplikasi SPPD KPPN Medan II apabila telah berhasil. 


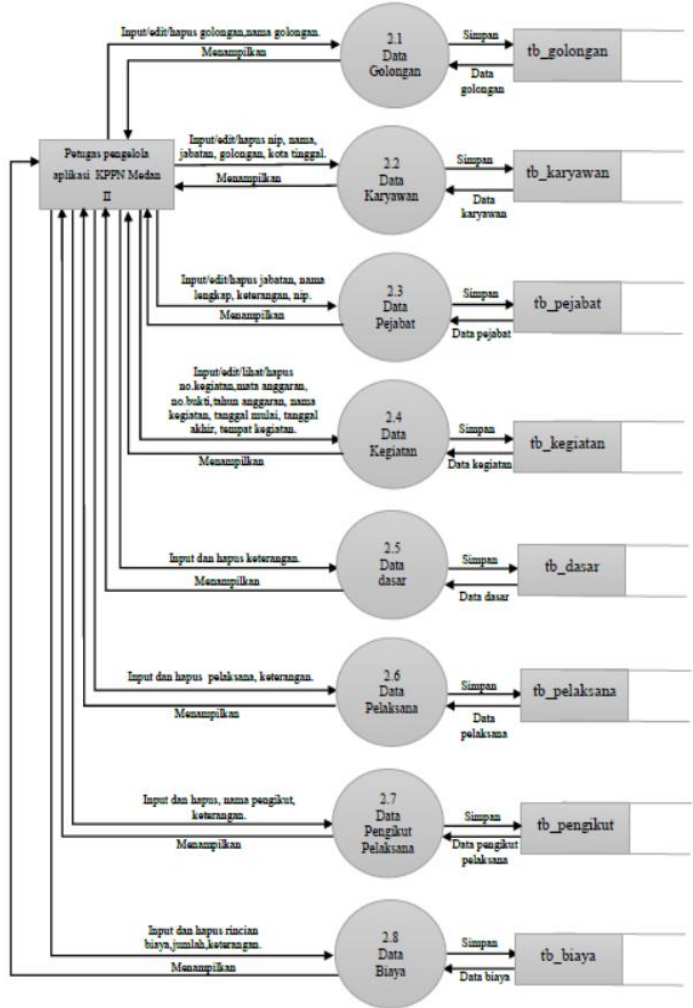

Gambar 5. DFD Level 2 proses pembuatan SPPD KPPN Medan II.

Pada proses pembuatan Surat Perintah Perjalanan Dinas (SPPD) ini dijelaskan bagaimana seorang petugas pengelola Aplikasi SPPD KPPN Medan II menginput data untuk pembuatan SPPD. Dimana petugas pengelola Aplikasi SPPD KPPN Medan II menginput setiap atribut yang diperlukan dalam pembuatan Surat Perintah Perjalanan Dinas (SPPD), seperti menginput nama, jabatan, golongan, tujuan, waktu, dan anggaran. Inputan ini akan masuk atau tersimpan didalam tabel-tabel yang berada didalam database aplikasi SPPD KPPN Medan II seperti pada gambar 5. DFD Level 2 Proses diatas.

\subsection{Perancangan basisdata}

Perancangan basisdata dilakukan untuk membuat sebuah perancangan tabel - tabel yang dibutuhkan dalam sebuah pembangunan sistem aplikasi SPPD KPPN Medan II berbasis website ini. Proses perancangan dilakukan dengan mengidentifikasi calon table yang dibutuhkan dalam sistem, kemudian dibuat conceptual data model untuk menentukan cardinalitas (relasi) antar entity.

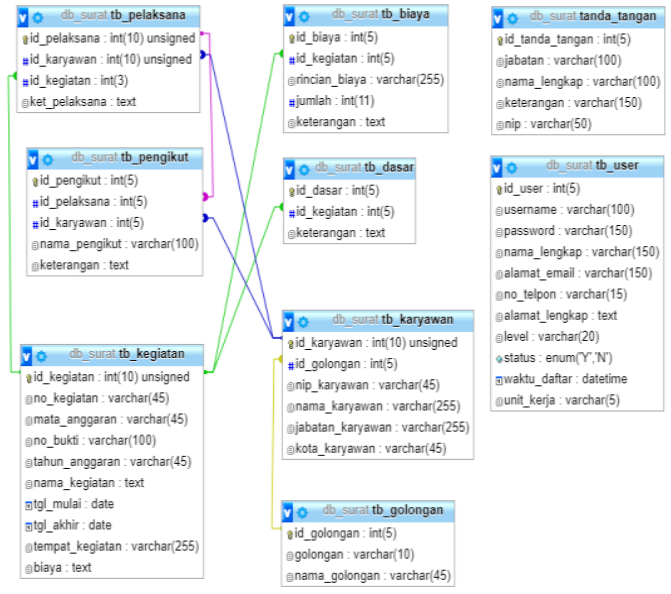

Gambar 6. Gambar relasi tabel antar tabel Database Aplikasi SPPD KPPN Medan II.

Pada aplikasi SPPD KPPN Medan II yang dirancang dan dibangun memiliki database untuk tempat penyimpanan datadata yang tersimpan di database dengan nama db_surat. Dimana database $\mathrm{db}$ surat memiliki 9 tabel diantaranya terdiri dari tanda_tangan, tb_biaya, tb_dasar, tb_golongan, tb_karyawan, tb_kegiatan, tb_pelaksana, tb_pengikut, tb_user.

\subsection{Flowmap sistem berjalan sistem aplikasi SPPD KPPN Medan II}

Pada flowmap ini proses alur data hingga menjadi sebuah surat SPPD yang lengkap. Pertama-tama pegawai memberikan surat disposisi kepada petugas pengelola aplikasi SPPD, kemudian petugas pengelola aplikasi SPPD memasukkan data pegawai dan pembuatan SPPD kedalam database dan kemudian SPPD dicetak lalu diberikan kepada bagian Kasubbag umum untuk diberikan persetujuan, apabila Kasubbag umum tidak setuju maka lembar SPPD dikembalikan kepada petugas pengelola aplikasi SPPD untuk di diposisikan kembali. Namun apabila Kasubbag umum setuju, lembar SPPD diberikan pengesahan kemudian dilakukan pengesahan Kasubbag umum lalu lembar SPPD di gandakan untuk lembar pertama diberikan kepada bagian arsip berkas dan yang lembar kedua diberikan kepada bagian keuangan untuk dirincikan biayanya kemudian SPPD diberikan kembali kepada pegawai yang akan melaksanakan 
perjalanan dinas. Berikut dapat kita lihat flowmap sistem berjalan SPPD.

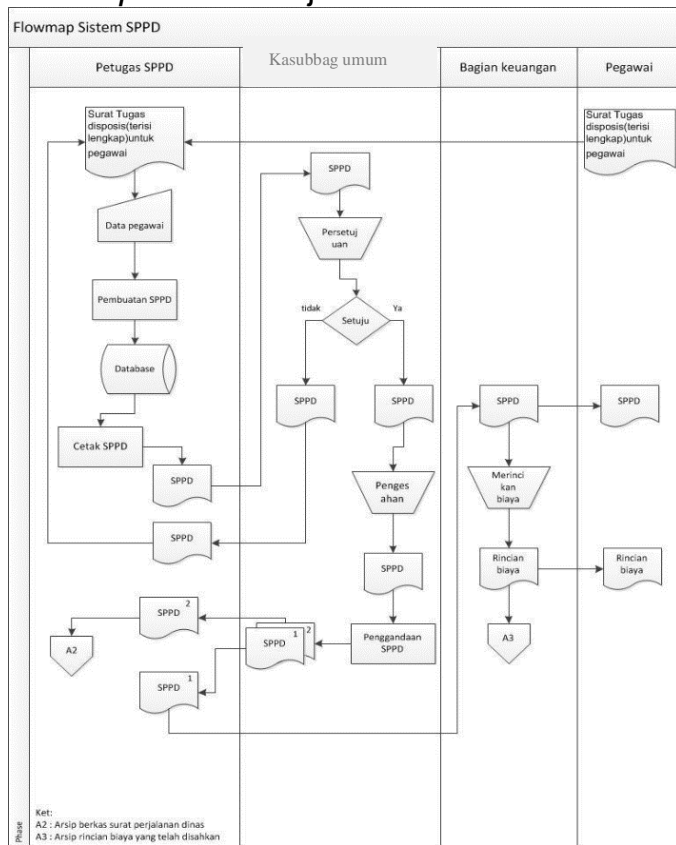

Gambar 7. Flowmap sistem yang berjalan.

\subsection{Implementasi User Interface}

User interface merupakan bentuk tampilan grafis yang berhubungan langsung dengan pengguna (user). Antarmuka pengguna berfungsi untuk menghubungkan antara pengguna dengan sistem operasi, sehingga komputer tersebut bisa digunakan

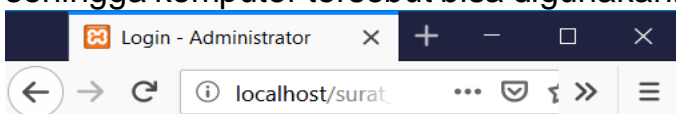

\section{TORM LOGIN}

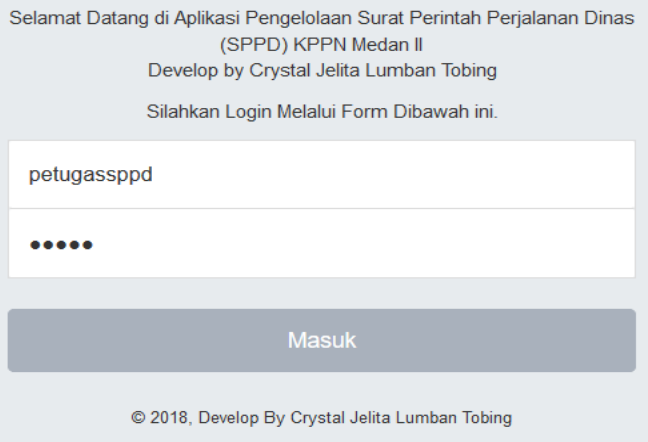

Gambar 8. User interface halaman petugas pengelola aplikasi SPPD KPPN Medan II.

Halaman pertama kali sebelum user masuk ke dalam sistem adalah halaman login, halaman login ini dirancang dan dibangun supaya user yang menggunakan sistem adalah user yang berhak dalam memasukkan data. Halaman dapat diakses jika seorang user telah mendaftar sebagai operator dan petugas pengelola Aplikasi SPPD di Kantor Pelayanan Perbendaharaan Negara (KPPN) Medan II di Seksi Kasubbag Umum. Sistem pendaftaran user dilakukan oleh petugas pengelola Aplikasi SPPD KPPN Medan II dengan mengakses form data user. Halaman ini hanya dapat diakses oleh user yang memiliki status petugas pengelola Aplikasi SPPD, Operator, dan pegawai KPPN Medan II. Dan seorang petugas pengelola Aplikasi SPPD hanya dapat menambah dan menghapus data user yang menggunakan sistem ini. Jika user telah masuk ke sistem maka user dapat mengolah data dengan mengakses menu sistem informasi. Seperti pada gambar 8 diatas.

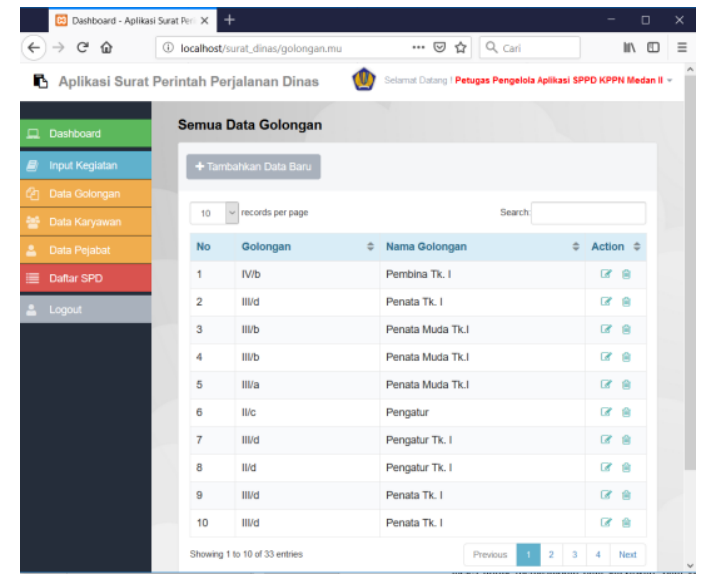

Gambar 9. User interface halaman input data golongan.

Pada sistem aplikasi SPPD KPPN Medan II ini akan terdapat pula halaman form input data golongan dimana halaman ini berfungsi sebagai tempat penginputan data golongan yang dimiliki oleh pegawai yang bekerja di KPPN Medan II. Pada form input data golongan karyawan dan pejabat KPPN Medan II dapat diinput oleh 2 user yaitu petugas pengelola Aplikasi SPPD dan operator (Kasubbag Umum). Dimana data golongan yang diinputkan berupa data golongan pejabat dan pegawai, dan data nama golongan. Data golongan diperlukan dalam mengelola pembuatan surat perintah perjalanan dinas. Seperti pada gambar 9 diatas. 


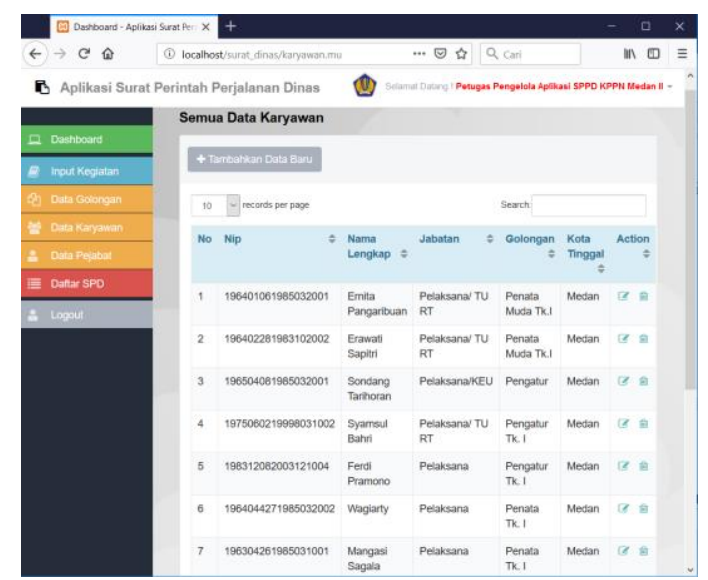

Gambar 10. User interface halaman input data pegawai.

Pada sistem aplikasi SPPD KPPN Medan II ini juga akan terdapat form input data karyawan yang berfungsi tempat menginput data jabatan karyawan. Form ini hanya dapat diakses oleh user dengan level operator dan petugas pengelola Aplikasi SPPD. Data yang diinput adalah nama lengkap, jabatan, golongan, dan kota tinggal. Untuk menyimpan user mengklik tombol button simpan. Hasil yang disimpan akan ditampilkan pada tabel. Untuk melakukan pengeditan user dapat mengklik button edit dimasing-masing baris pada daftar yang telah diinputkan atau user dapat menghapus data dengan mengklik hapus. Seperti pada gambar 10 diatas.

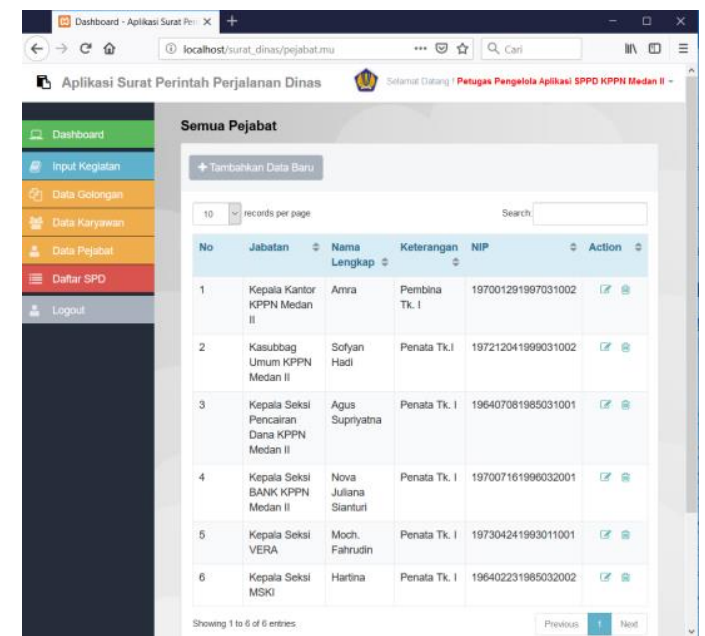

Gambar 11. User interface halaman input data pejabat.

Pada tampilan menu input data pejabat juga akan terdapat form input data karyawan yang berfungsi tempat memasukkan biodata pegawai. Form ini hanya dapat diakses oleh user dengan level operator dan petugas pengelola Aplikasi SPPD KPPN Medan II. Data yang diinput adalah jabatan, nama lengkap, keterangan, dan NIP. Seperti pada gambar 11 diatas.

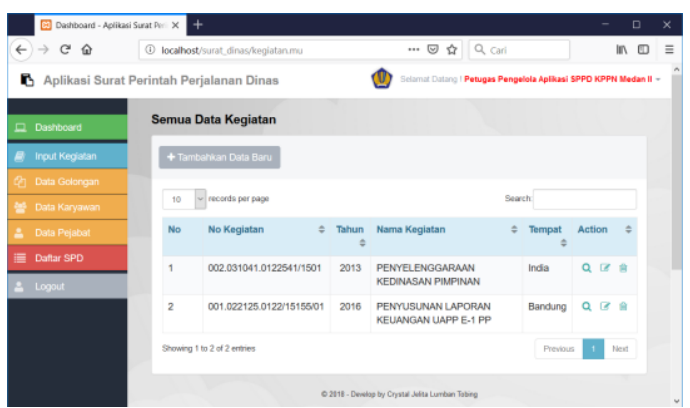

Gambar 12. User interface halaman input data kegiatan SPPD KPPN Medan II.

Pada sistem aplikasi SPPD KPPN Medan II ini akan terdapat halaman form input data kegiatan yang digunakan untuk mengelola pembuatan surat perintah perjalanan dinas bagi para karyawan yang diperintahkan untuk melakukan perjalanan dinas. Jadi sebelum mengelola pembuatan surat perintah perjalanan dinas perlu memasukkan data-data yang diperlukan dalam melakukan penginputan kegiatan agar dapat mempelancar dalam pembuatan surat perintah perjalanan dinas. Setelah data-data kegiatan diinput maka petugas pengelola Aplikasi SPPD dapat mengelola atau mencetak keluaran dari aplikasi SPPD KPPN Medan II tersebut berupa surat keluar yaitu surat perintah perjalanan dinas beserta surat perincian biaya yang akan digunakan selama melakukan perjalanan dinas. Seperti pada gambar 12 diatas.

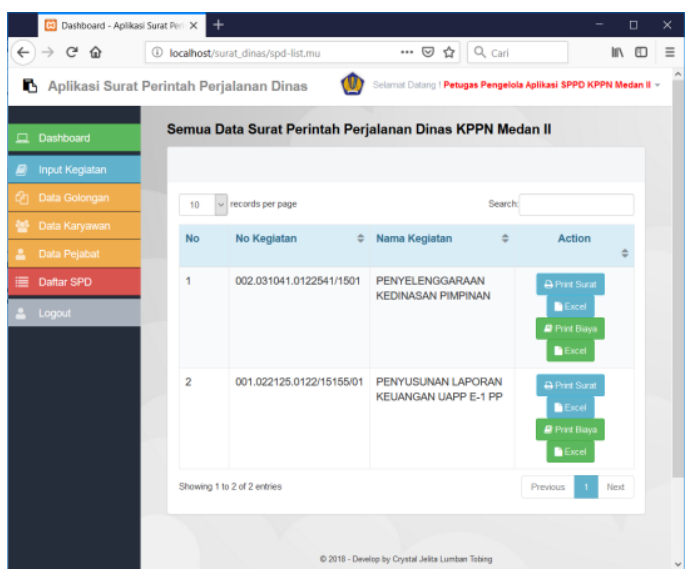

Gambar 13. User interface halaman view data SPPD KPPN Medan II. 
Pada sistem aplikasi SPPD KPPN Medan II ini akan terdapat halaman menampilkan tabel dari data untuk SPPD KPPN Medan II telah dimasukkan ke sistem aplikasi SPPD KPPN Medan II, sehingga operator yang hanya memiliki hak akses untuk memasukkan data karyawan, data golongan, dan data pejabat serta dapat melihat hasil laporan berupa tabel yang telah dibuat SPPD KPPN Medan II oleh petugas pengelola Aplikasi SPPD KPPN Medan II untuk karyawan yang akan melakukan perjalanan dinas. Dan sebagai karyawan memiliki hak akses ada yang sama seperti hak akses operator yaitu dapat melihat laporan berupa tabel daftar karyawan yang akan melakukan perjalanan dinas. Seperti pada gambar 13 diatas.

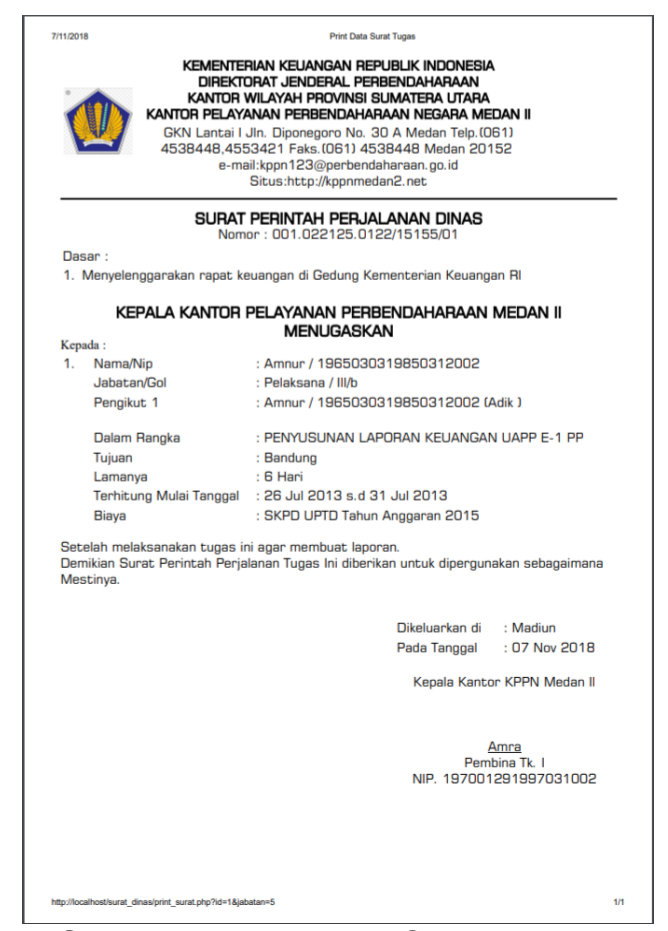

Gambar 14. Tampilan Surat Perintah Perjalanan Dinas (SPPD).

Pada sistem aplikasi SPPD KPPN Medan II tersebut menghasilkan keluaran (output) berupa Surat Perintah Perjalanan Dinas (SPPD). Dimana fungsi utama aplikasi SPPD tersebut untuk menghasilkan surat perintah perjalanan dinas sehingga dengan seperti ini sistem yang dirancang secara sistematis dapat membantu pekerjaan petugas pengelola Aplikasi SPPD tepat, cepat, efisien serta efektif. Seperti pada gambar 14 diatas.

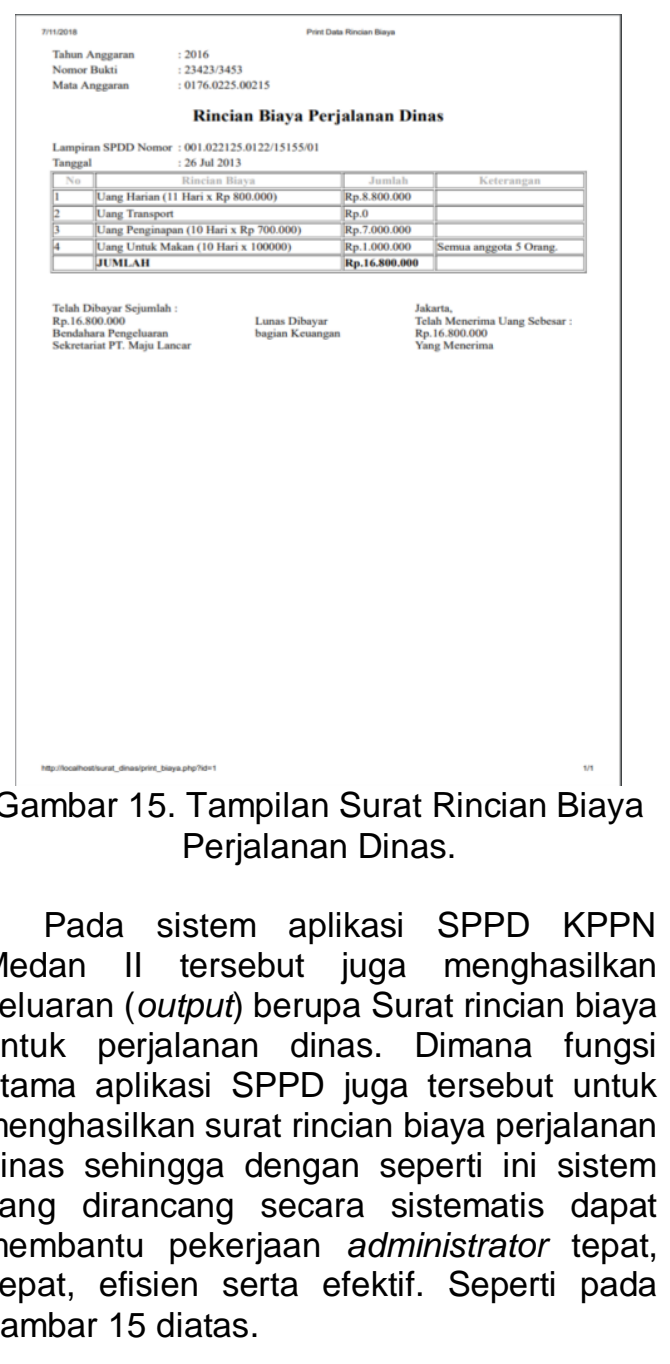

\section{Kesimpulan}

Aplikasi SPPD KPPN Medan berbasis web yang dibangun dapat mempermudah serta meringankan tugas dalam mengelola surat perintah perjalanan dinas yang dari manual menjadi praktis dan hemat waktu dalam pembuatannya, sehingga kendalakendala yang selama ini terjadi terbantu.

Dilihat dari petugas untuk membuat Surat PPD tidak perlu lagi membuat secara manual yaitu diketik di microsoft word serta pada aplikasi ini dapat menyimpan data pegawai, pejabat, data kegiatan SPPD, serta rincian biaya perjalanan dinas disimpan didalam database secara sistematis dan terstruktur. Sementara dari pihak para pegawaia atau para pejabat KKPN yang lainnya juga dapat melakukan pemantauan atau melihat daftar para pegawai yang telah melakukan perjalanan dinas.

Penerapan aplikasi SPPD KPPN Medan II berbasis web ini akan berjalan baik 
jika ada sebuah dukungan yang baik dari pihak - pihak terkait. Dengan dukungan dari berbagai pihak maka, sistem yang dibangun ini akan tambah mempermudah petugas SPPD dalam mengelola SPPD secara efektif dan cepat terhadap mengelola membuat surat perjalanan dinas buat para pegawai atau para pejabat yang akan melakukan perjalanan dinas.

\section{Referensi}

Bangun, R., Surat, A., Perjalanan, P., Negara, P., \& li, M. (2018). Laporan akhir kerja praktek.

Informatika, J. I., Prototype, B., \& Evaluation, P. (2016). SISTEM INFORMASI AKADEMIK AMIK IBRAHIMY, 1(1), 17-23.

Rabbani, Rizqiena Mulya. 2017. Tugas Akhir Aplikasi Surat Perintah Perjalanan Dinas PoliteknikNegeri Batam berbasis Website, Batam : Politeknik Negeri Batam.
Saputra, Andana Eka. 2015. Laporan Akhir Perancangan Sistem Informasi Surat Perintah Perjalanan Dinas Di PT. Bank SulutGo Kantor Pusat Manado, Manado : Politeknik Negeri Manado.

Susanto, R., Andriana, A. D., Susanto, R., \& Andriana, A. D. (n.d.). PERBANDINGAN MODEL WATERFALL DAN PROTOTYPING, 14(1), 41-46.

Umam, A. S. (n.d.). Sistem Keamanan Ruangan Berbasis WEB Menggunakan Webcam dan Sensor PIR, 1-6. 